\title{
Multisystemic eosinophilic epitheliotropic disease in a horse in Brazil
}

\author{
Cláudio João Mourão Laisse ${ }^{1}$ Lismara Castro do Nascimento $^{1}$ Welden Panziera $^{1}$ \\ Elizabeth Caldas Soares ${ }^{2}$ Denise Bicca Fernandes ${ }^{2}$ Júlio César Westphalen $^{3}$ Luciana Sonne $^{1}$ \\ Saulo Petinatti Pavarini ${ }^{1}$ David Driemeier ${ }^{1}$
}

\author{
${ }^{1}$ Setor de Patologia Veterinária (SPV), Universidade Federal do Rio Grande do Sul (UFRGS), Av. Bento Gonçalves, 9090, Bairro Agronomia, \\ 91540-00, Porto Alegre, RS, Brasil. E-mail: davetpat@ufrgs.br. "Corresponding author. \\ ${ }^{2}$ Jockey Club do Rio Grande do Sul, Porto Alegre, RS, Brasil. \\ ${ }^{3}$ Quarto Regimento de Polícia Montada, Brigada Militar, Porto Alegre, RS, Brasil.
}

ABSTRACT: Equine multisystemic eosinophilic epitheliotropic disease (MEED) is a rare disease, characterized by eosinophilia and eosinophilic infiltration of several organs. A 5-year-old horse presented pruritus, areas of alopecia, and moderate eosinophilia. The horse was treated with corticosteroids and antibiotics without substantial improvement; and after the disease progressed to fever, diarrhea, gastric reflux and progressive weight loss. Due to poor prognosis the horse was euthanized. Necropsy revealed poor body condition, multiple to coalescing foci of alopecia, with epidermal ulcerations and crusts on the head and distal parts of the limbs. The proximal duodenum was enlarged, with 3 intraluminal nodules. Histopathological evaluation revealed eosinophilic granulomas in the skin, oral mucosa, duodenum, pancreas, and mesenteric lymph nodes, which were associated with infiltrates of eosinophils, lymphocytes, macrophages, multinucleated giant cells, and occasional plasma cells, along with fibrovascular connective tissue proliferation. MEED should be included in the differential diagnosis of horses with skin lesions concomitant with clinical signs of gastrointestinal illness.

Key words: Eosinophilia, eosinophilic granuloma, histopathology, horse.

Doença multissistêmica eosinofílica epiteliotrópica em um eqüino no Brasil

RESUMO: Doença multissistêmica eosinofilica epiteliotrópica (DMEE) dos equinos é uma doença rara que se caracteriza por eosinofilia e infiltrado de eosinófilos em vários órgãos. Um equino com cinco anos de idade apresentou prurido, áreas de alopecia e eosinofilia moderada. $O$ equino foi tratado com corticosteroides e antibióticos sem melhora clínica significativa, com evolução para febre, diarreia, refluxo gástrico e emagrecimento progressivo. Devido a prognóstico desfavorável, o equino foi eutanasiado. Na necropsia, apresentou condição corporal ruim, áreas multifocais a coalescentes de alopecia, ulceração da epiderme e crostas na cabeça e parte distal dos membros. A região proximal do duodeno estava aumentada de volume e apresentou três nódulos intraluminais. No exame histopatológico foram observados granulomas eosinofilicos associados a infiltrado de eosinófilos, linfócitos, macrófagos, células gigantes multinucleadas, ocasionais plasmócitos e proliferação de tecido conjuntivo fibroso na pele, mucosa oral, duodeno, pâncreas e linfonodos mesentéricos. DMEE deve ser considerada um diagnóstico diferencial em equinos que apresentem concomitantemente lesões cutâneas e sinais de doença gastrointestinal.

Palavras chave: Eosinofilia, granuloma eosinofilico, histopatologia, equino.

Multisystemic eosinophilic epitheliotropic disease (MEED) is a rare, sporadic, and chronic wasting disease of horses, which is characterized by severe peripheral eosinophilia and eosinophilic infiltration of multiple organs (LA PERLE et al., 1998; HENSON et al., 2002; BLACK \& MACE, 2004). The disease occurs generally, but not exclusively, in young horses, and equally affects both genders. Standardbred and thoroughbred breeds are most frequently affected (SANFORD, 1989; BLACK \& MACE, 2004; MAULDIN \& PETERS-KENNEDY, 2016).

The pathogenesis of MEED in horses remains unclear. Eosinophilia is frequently associated with parasitism, hypersensitivity, lymphoma, and genetic disorders (NIMMO WILKIE et al., 1985; LA PERLE et al., 1998). Associated signs vary, based on the affected organs. The most common signs include anorexia, diarrhea, weight loss, pruritus, and exfoliative dermatitis (SANFORD, 1989; HENSON et al., 2002; GEHLEN et al., 2003). The final morphologic diagnosis of MEED is based on histopathological examination (SCHUMACHER et al., 2000).

Equine MEED has been reported in several countries, including Canada (NIMMO WILKIE et al., 1985; SANFORD, 1989), New Zealand (BLACK \& MACE, 2004), United Kingdom (HENSON et al., 2002), Belgium (BOSSELER et al. 2013), and the United States of America (McCUE 
et al., 2003; PUCHEU-HASTON \& DEL PIERO, 2013). However, equine MEED has not yet been reported in Brazil. Here, we described the clinical and anatomopathological features of a case of MEED in a horse in southern Brazil.

Between May and July 2015, in Porto Alegre, State of Rio Grande do Sul, Brazil $\left(30^{\circ} 01\right.$ ' 59 "S and 51 13 ' 48" W), 6 horses (Equus caballus) belonging to the same owner presented a history of pruritus and multifocal areas of hair loss suggestive of allergic dermatitis caused by hypersensitivity to Culicoides spp. Horses were treated with deltamethrin, moxidectin, bactericidal ointment, and insect repellent. Fifteen days after the initiation of treatment, 5 horses showed improvement, while a 5-year-old mixed-breed male horse showed worsening signs.

Re-evaluation 2 months after the first examination revealed that the horse remained pruritic, and had multiple and coalescing foci of alopecia, with ulcerations and crusting on his head and the distal areas of both the thoracic and pelvic limbs (Figure 1A). His blood cell count showed moderate eosinophilia $\left(1,545 \mu \mathrm{L}^{-1}\right.$, reference value (RV): $0-1,000 \mu \mathrm{L}^{-1}$ ) and neutrophilic leukocytosis $\left(8,385 \mu \mathrm{L}^{-1}, \mathrm{RV}: 600-4,000 \mu \mathrm{L}^{-1}\right)$. Serum biochemistry showed a slightly decreased total serum protein concentration (48g L $\mathrm{g}^{-1}, \mathrm{RV}: 52-79 \mathrm{~g} \mathrm{~L}^{-1}$ ) (KANECO et al., 1997). The horse was treated with triamcinolone, enrofloxacin (later replaced by levofloxacin), and ivermectin, with some improvement. However, a few days after the cessation of corticosteroid therapy, the horse's clinical condition worsened; and he presented anorexia, progressive weight loss, diarrhea, gastric reflux, dehydration, intermittent fever, and subcutaneous cervical edema. Because of progressive worsening of his general condition, he was euthanized by xylazine, sodium thiopental, and potassium chloride, according to ordinance 714 of the Conselho Federal de Medicina Veterinária (CFMV, 2002).

At necropsy examination, the horse was in poor body condition. The head and distal regions of both thoracic and pelvic limbs showed multiple and coalescing foci of alopecia, sometimes associated with ulcers and crusting. Subcutaneous edema was seen in the ventral thoracic and abdominal regions. The proximal duodenum was enlarged and showed mural thickening and 3 intraluminal nodules ranging from $2.5 \times 2.0 \times 2.0 \mathrm{~cm}$ to $5.0 \times 4.0 \times 4.0 \mathrm{~cm}$, which had caused a partial obstruction of the duodenal lumen (Figure 1B). Nodules were whitish well demarcated and irregular. Their cut surfaces were whitish, firm, and had multiple yellow foci, 1-3mm in diameter, and areas containing a yellowish gelatinous material. The duodenal mucosa showed multifocal ulcerations. The pancreas and mesenteric lymph nodes were enlarged, irregular, and the cut surface was firm. Gastrointestinal parasites were not observed, and the other organs appeared normal.

Tissue samples of skin, oral mucosa, lung, heart, thyroid, parathyroid, small and large intestines, spleen, liver, pancreas, adrenal gland, kidneys, urinary bladder, mesenteric lymph nodes, and brain were collected and fixed in 10\% neutral buffered formalin, embedded in paraffin, sectioned at $5 \mu \mathrm{m}$, and stained with hematoxylin and eosin (HE). Paraffin sections of the skin, oral mucosa, duodenum, pancreas and mesenteric lymph nodes were stained with Grocott's methenamine silver stain (GMS) for the identification of Pythium insidiosum.

Histologically, the skin, oral mucosa, duodenum, pancreas, and mesenteric lymph nodes contained multifocal eosinophilic granulomas that were characterized by a central core of eosinophilic material surrounded by eosinophils, macrophages, multinucleated giant cells, occasional plasma cells, and fibrovascular connective tissue proliferation (Figure 1C). Eosinophilic granulomas were distributed transmurally in the duodenum, but in the skin showed multifocal distribution in the dermis. Eosinophilic granulomas in the skin and duodenum often presented eosinophilic degenerate collagen bundles (collagenolisis) and central mineralization (Figure 1D) respectively. Epidermis showed ulcerated areas with fibrin deposits associated with rod-shaped bacteria. Sebaceous adenitis and folliculitis were seen in the dermis. None of the tissues stained by GMS were positive for fungal structures. The final diagnosis of MEED was based on the clinicopathological findings.

Multisystemic eosinophilic epitheliotropic disease is an extremely rare equine disease that affects several organ systems. The condition has not yet been described in Brazil. Clinical signs and age of the affected horse are consistent with those described in the literature for MEED (NIMMO WILKIE et al., 1985; HENSON et al., 2002; BLACK \& MACE, 2004; BOSSELER et al., 2013). Cutaneous lesions occurred in $63 \%$ of MEED cases (SCHUMACHER et al., 2000) and must be differentiated from skin lesions occurring in dermatophytosis, pemphigus foliaceus, systemic lupus erythematosus, bullous pemphigus, and erythema multiforme (SCOTT \& MILLER, 2003). Horses with MEED frequently showed areas of alopecia and exudative dermatitis, with epidermal ulcerations, hyperkeratosis, and 


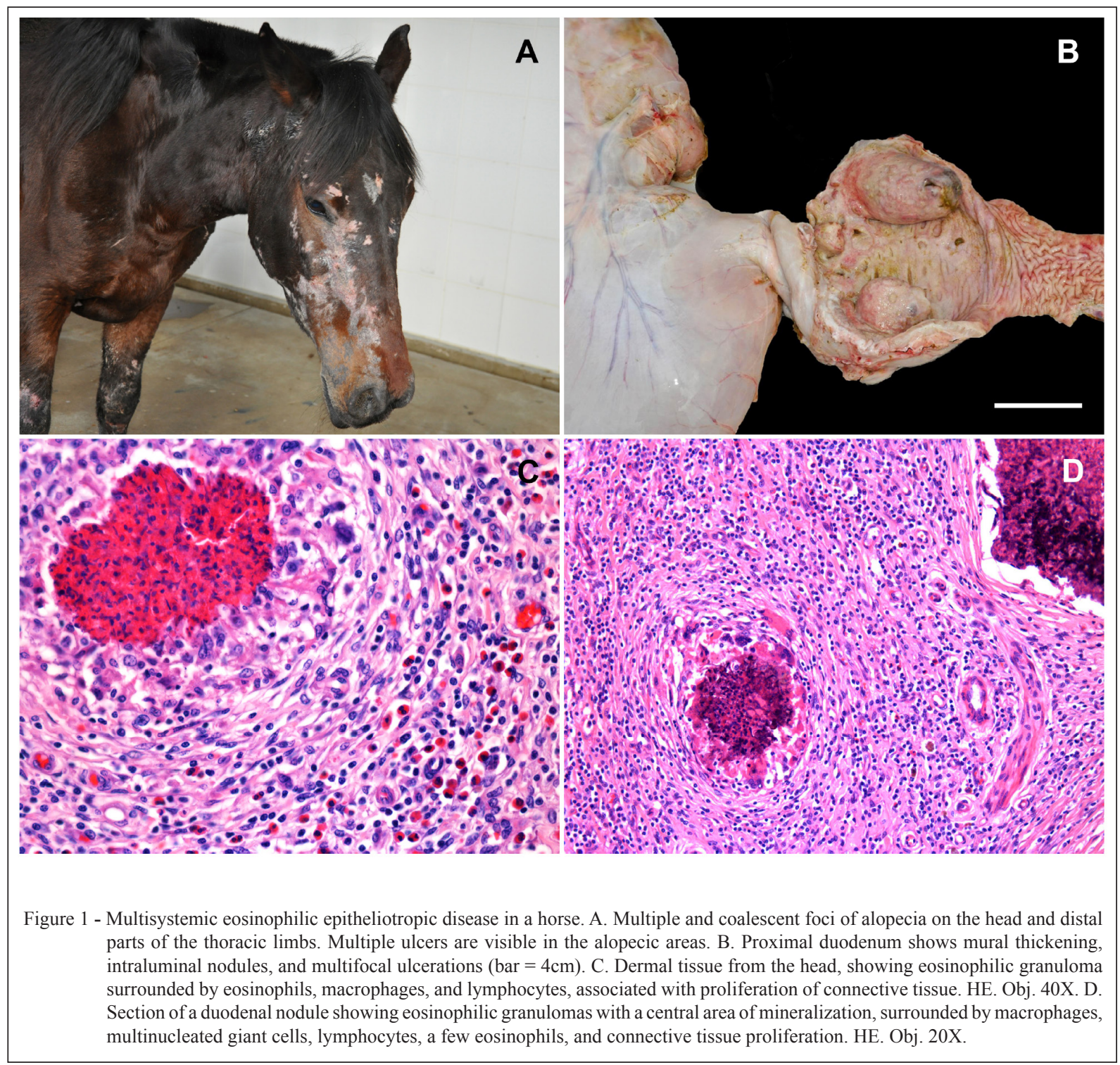

lichenification. The head and lower parts of the legs, especially the coronary bands, are always involved (NIMMO WILKIE et al., 1985; HENSON et al., 2002; BOSSELER et al., 2013; MAULDIN \& PETERS-KENNEDY, 2016).

MEED must also be differentiated from other chronic inflammatory bowel diseases of horses, including granulomatous enteritis (GE), lymphoplasmacytic enterocolitis (LE), and idiopathic eosinophilic enterocolitis (EC). Diarrhea and weight loss are more frequent in horses with MEED, and occur in $65 \%$ and $100 \%$, respectively, of cases. Chronic pancreatitis occurs in MEED, but does not occur in horses with GE, LE, or EC (SCHUMACHER et al., 2000).

Skin manifestations of equine MEED could be due to the malabsorption of fat-soluble vitamins such as vitamin $A$, which is associated with pancreatic destruction or chronic enteritis (NIMMO WILKIE et al., 1985). In this case, gastric reflux might have occurred because of partial obstruction of the duodenal lumen due to the intraluminal nodules, while the horse's progressive weight loss was secondary to diarrhea and intestinal malabsorption.

The horse in this case presented with eosinophilia and leukocytosis of the peripheral 
blood. Eosinophilia occurs in approximately $14 \%$ of MEED cases (BOSSELER et al., 2013; MAULDIN \& PETERS-KENNEDY, 2016), and leukocytosis was also previously reported (GEHLEN et al., 2003; BOSSELER et al., 2013). Etiopathogenesis of MEED is unknown; various factors could be involved in the stimulation and chemotaxis of eosinophils that ultimately lead to multisystemic infiltrates (LA PERLE et al., 1998; ROUFOSSE et al., 2004; MAULDIN \& PETERS-KENNEDY, 2016). Deregulated production of eosinophilopoietic cytokines (granulocyte-macrophage colonystimulating factor, interleukin-3, and interleukin 5 [IL-5]) is responsible for hypereosinophilic syndromes in humans (ROUFOSSE et al., 2004). The authors of a report on equine MEED concurrent with intestinal lymphoma have suggested that the clonal proliferation of $\mathrm{T}$ lymphocytes triggers proliferation of eosinophils through secretion of IL-5 (LA PERLE et al., 1998).

We suggested that hypersensitivity to Culicoides spp., which affected the 6 horses, might have induced MEED in the 1 horse reported here, who did not respond to treatment with deltamethrin, moxidectin, bactericidal ointment, and insect repellent. According to Mauldin and Peters-Kennedy (2016) recurrent episodes of type I hypersensitivity associated with ingested, inhaled, or parasitic antigens might be involved in the development of MEED. A Culicoides bite can lead to a type I hypersensitivity (immediate) reaction (CRAIG, 2011). The horse showed no evidence of infestation by gastrointestinal parasites.

Hypoproteinemia is a common finding in equine MEED cases (LA PERLE et al., 1998; GEHLEN et al., 2003; ROUFOSSE et al., 2004). According to HENSON et al. (2002), it is detected in $58 \%$ of MEED cases, and reflects the protein-losing enteropathy seen in affected horses.

Treatments for MEED include corticosteroids, antihelminthic agents, and antibiotics (SCHUMACHER et al., 2000). Treatment with prednisolone (HENSON et al., 2002) or dexamethasone combined with trimethoprimsulfamethoxazole and an antihistamine (McCUE et al., 2003) might improve a horse's clinical condition during the early stages of the disease. In this case, we noted some clinical improvement during the horse's treatment with triamcinolone and enrofloxacin. Most horses with MEED die or are euthanized because of the poor prognosis of horses with this disease, or because of lack of response to treatment (NIMMO WILKIE et al., 1985; HENSON et al., 2002; GEHLEN et al., 2003; BLACK \& MACE, 2004).
The histopathological features of this case are similar to those previously described (SANFORD, 1989; HENSON et al., 2002; BOSSELER et al., 2013). Apart from the affected organs in this case, histopathological MEED lesions have also been described in the lungs, liver, salivary glands, esophagus, kidneys, and biliary epithelium (NIMMO WILKIE et al., 1985; BOSSELER et al., 2013; MAULDIN \& PETERS-KENNEDY, 2016). Histologically, MEED should be differentiated from equine intestinal pythiosis, since infection by Pythium insidiosum can induce a pyogranulomatous and eosinophilic enteritis that contains foci of necrosis (BEZERRA JÚNIOR et al., 2010). The diagnosis of equine intestinal pythiosis was excluded in this horse, because no fungal structures were observed on GMS-stained slides of tissue specimens.

Histopathological examination allowed the differentiation of MEED from other equine diseases associated with cutaneous and gastrointestinal manifestations and from diseases associated with eosinophilia and eosinophilic infiltration of various organs.

\section{ACKNOWLEDGEMENTS}

The first author's Phd scholarship was cofunded by Conselho Nacional de Desenvolvimento Científico e Tecnológico (CNPq) and The World Academy of Science (TWAS): CNPq-TWAS Fellowships Programme-2012.

\section{REFERENCES}

BEZERRA JÚNIOR, P.S. et al. Equine intestinal pythiosis in Southern Brazil. Arquivo Brasileiro de Medicina Veterinária e Zootecnia, v.62, n.2, p.481-483, 2010. Available from: <http:// www.ncbi.nlm.nih.gov/pubmed/23441858>. Accessed: May. 30, 2016. doi: 10.1590/S0102-09352010000200031.

BLACK, A.M.; MACE, J.C. Multisystemic eosinophilic epitheliotropic disease (MEED) in a horse. New Zealand Veterinary Journal, v.52. n.1, p.49, 2004. Available from: $<$ http:// www.tandfonline.com/doi/pdf/10.1080/00480169.2004.36395>. Accessed: Nov. 09, 2016.

BOSSELER, L. et al. Equine multisystemic eosinophilic epitheliotropic disease: a case report and review of literature. New Zealand Veterinary Journal, v.61, n.3, p.177182, 2013. Available from: <http://www.ncbi.nlm.nih. gov/pubmed/23441858>. Accessed: May. 15, 2016. doi: 10.1080/00480169.2012.753569.

CONSELHO FEDERAL DE MEDICINA VETERINÁRIA (CFMV). Resolução $n^{0} 714$, de 20 de junho de 2002. Publicada no DOU de 21-06-2002, Seção 1, p.201. 
CRAIG, M. Culicoides hypersensitivity in horses. Companion Animal, v.16, p.5-9, 2011. Available from: $<\mathrm{http}$ //onlinelibrary.wiley. com/doi/10.1111/j.2044-862.2011.00052.x/pdf>. Accessed: Nov. 22, 2016. doi: 10.1111/j.2044-3862.2011.00052.x.

GEHLEN, H. et al. Multisystemic eosinophilic disease in a standardbred mare combined with generalized lymphadenitis. Journal of Equine Veterinary Science, v.23, n.5, p.216-219, 2003. Available from: <http://www.j-evs.com/article/S07370806(03)70008-2/pdf>. Accessed: Nov. 09, 2016. doi: 10.1053/ jevs.2003.65.

HENSON, F.M.D. et al. Multisystemic eosinophilic epitheliotrophic disease in a Welsh pony. Equine Veterinary Education, v.14, n.4, p.176-178, 2002. Available from: <http:// onlinelibrary.wiley.com/doi/10.1111/j.2042-3292.2002. tb00165.x/abstract>. Accessed:June. 12, 2016. doi: 10.1111/ j.2042-3292.2002.tb00165.x.

KANECO, J.J. et al. Clinical biochemistry of domestic animals. 5.ed. San Diego: Academic, 1997. 932p.

LA PERLE, K.M. et al. Multisystemic, eosinophilic, epitheliotropic disease with intestinal lymphosarcoma in a horse. Veterinary Pathology, v.35, n.2, p.144-146, 1998. Available from: <http:// www.ncbi.nlm.nih.gov/pubmed/9539369>. Accessed: June. 12, 2016.

MAULDIN, E.; PETERS-KENNEDY, J. Integumentary system. In:MAXIE, M.G. Jubb, Kennedy, and Palme's pathology of domestic animals. 6.ed. St. Louis, Missouri: Elsevier, 2016. V.1, p.509-736.

McCUE, M.E. et al. Dexamethasone for treatment of multisystemic eosinophilic epitheliotropic disease in a horse. Journal of the American Veterinary Medical Association, v.223, n.9, p.1320-1323, 2003. Available from: <http://www. ncbi.nlm.nih.gov/pubmed/14621221>. Accessed: July. 12, 2016.

NIMMO WILKIE, J.S. et al. Chronic eosinophilic dermatitis: a manifestation of a multisystemic, eosinophilic, epitheliotropic disease in five horses. Veterinary Pathology, v.22, n.4, p.297-305, 1985. Available from: <http://www.ncbi.nlm. nih.gov/pubmed/2930933>. Accessed: June. 25, 2016. doi: $10.1177 / 030098588502200401$.

PUCHEU-HASTON, C.M.; DEL PIERO F. Equine multisystemic eosinophilic epitheliotropic disease. Equine Veterinary Education, v.25, n.12, p.614-617, 2013. Available from: <http:// onlinelibrary.wiley.com/doi/10.1111/eve.12107/abstract $>$. Accessed: May. 15, 2016. doi:10.1111/eve.12107.

ROUFOSSE, F. et al. Recent advances in pathogenesis and management of hypereosinophilic syndromes. Allergy, v.59, n.4, p.673-689, 2004. Available from: <http://www.ncbi.nlm. nih.gov/pubmed/15180753>. Accessed: June. 12, 2016. doi: 10.1111/j.1398-9995.2004.00465.x.

SANFORD S.E. Multisystemic eosinophilic epitheliotropic disease in a horse. Canadian Veterinary Journal, v.30, p.253-254, 1989. Available from: <https://www.ncbi.nlm.nih. gov/pmc/articles/PMC1680994/pdf/canvetj00556-0055.pdf>. Accessed: Nov. 09, 2016.

SCHUMACHER, J. et al. Chronic idiopathic inflammatory bowel disease of the horse. Journal of Veterinary Internal Medicine, v.14, n.3, p.258-265, 2000. Available from: <http://www.ncbi.nlm. nih.gov/pubmed/10830538>. Accessed: June. 12, 2016.

SCOTT, D.W.; MILLER, W.H. Miscellaneous skin diseases:multisystemic eosinophilic epitheliotropic disease. In: . Equine dermatology. Philadelphia: Saunders, 2003. p.661-695 